\title{
Da'wah Ethics in Candra Malik's Sufistic Literature
}

\author{
Imron Amrullah ${ }^{1}$, Hetty Purnamasari ${ }^{2}$, Ni Nyoman Sarmi ${ }^{3}$, Imayah $^{4}$ \\ \{imron.amrullah@unitomo.ac.id ${ }^{1}$, hetty@unitomo.ac.id ${ }^{2}$,ni.nyoman@unitomo.ac.id $\left.{ }^{3}\right\}$ \\ 1,2,3,4Fakultas Keguruan dan Ilmu Pendidikan, Universitas Dr. Soetomo, Indonesia
}

\begin{abstract}
This study aims to uncover the ethics of Sufi mysticism in the work of Candra Malik. For Candra Malik, the way of life taken is the path of Sufism. All aspects of his life were used as a medium of propaganda to convey the teachings of Sufism. The method used in this research is the descriptive method. The approach used is a Sufistic approach that emphasizes the ethical teachings in Sufism that have influence and can be used in everyday life. The findings in this study related to the ethics of Candra Malik's Sufistic preaching include; first, ethical behavior is reflected in self-recognition of mistakes and always apologizes with the aim of building self-awareness; second, the ethics of inviting to be found in the way taken must be smooth, gentle, and full of love; and third, the ethics of conveying in Sufism teachings must use the heart so that the message received directly enters the heart.
\end{abstract}

Keywords: Ethics of behaving, inviting, conveying.

\section{Introduction}

There are various solutive approaches used by a dai in carrying out his $d a^{\prime} w a h$, including the Sufistic approach. When day mostly uses fiqh daily as a matter of indictment, it is different from Candra Malik. In each of his preaching, Candra Malik uses Sufism material which is packaged in various arts, ranging from literature, music, or film. The $d a^{\prime} w a h$ brought by Candra Malik is in line with the da'wah carried out by Sunan Kali Jaga by using local arts and culture as well as inserting teachings and values of Sufism. There are three basic elements built according to Nasr related to Sufism, namely philosophy, ethics, and methods.[1] The ethics of $d a^{\prime} w a h$ carried out like this gives a fresh breeze amid propaganda that tends to be radical in speech and action. A dai is required to understand the conditions of the community so that the teachings delivered can be well received. The passion of a community group towards the teachings conveyed is a reflection that the teachings delivered are well received. The teachings of Sufism are more concerned with behavior to get closer to Allah. because the whole in the life of the salik is filled with the remembrance of Allah SWT. Humanity ethics gives a high value of humanism[2]. This is reflected in everyday attitudes that prioritize introspection, cleanse the heart with zikr[3]. It was also a finding obtained In'Amuzzahidin that Ki Saleh Darat who was a teacher from Kartini emphasized the Sunni-amali Sufism teachings which immediately became a daily practice and refused the direction of philosophical Sufism[4]. The teachings of Sufism also have a stage that becomes the process of a salik's journey, namely mahabbah, ma'rifat, ittihad, hulul, and wahda al-wujud. This level is passed through the qalb-ruh-sir and alfana-albaqa processes Tasmin Tanggareng[5]. 
Candra Malik's Sufism teachings are seen in each of his works, especially in his poetry. The poems written by Candra Malik use simple language but have deep meaning. The power of simple language contains a lot of $d a^{\prime} w a h$ ethics in aspects of attitude, conveying, and in inviting a lot of people to love, especially among young people. In accordance with the findings Rahman that the process through which a salik, namely search, sacrifice, conviction, freedom, wonder, and lack self[6]. The theme of love is a topic that is always used and never used up to be discussed. Love in the discussion is not always aimed at couples, but love whose scope is wider and more meaningful in the nature of God. In line with the opinion of Hamka, a Sufi must place God on a scale of monotheism. Tawhid in the sense of God Almighty is in a transcendent position (being outside and above, separate from beings) but is close to the heart (Qalb) of mankind[7]. So that Sufism as morality spearheads humans in interacting with others. Sufism must be reflected in everyday attitudes and behavior[8].

Supriadi in tasawuf teachings, a salik has the belief that cleanliness of the heart influences divine light. When one's heart is clean, divine light can enter, but when one's heart is dirty, the divine light is difficult to enter and cannot even enter[9]. Sufistic teachings also have an impact on social renewal in society[10]. So that it is in accordance with Islamic teachings, as stated by Afrizal Nur that Sufism in accordance with Islam is Sufism which does not conflict with Islamic teachings[11]. Andarwati in her research distinguished urban sufism and rural sufism. Both are distinguished in how to practice Sufism[12]. In fact, Sauqi Fataqi built the construction of Sufic reasoning into several parts, including; God as the center, paying attention to aspects of specialness and sincerity, diversity, highlighting the power of taste and spirituality, and mystical reasoning constructed through inclusive and tolerant religious understanding[13].

The study of sufistic work is evolving and begins to enter the digital world. Candra Malik's work entitled \#FatwaRindu anthology of Love 1001 Rindu was originally written in social media twitter and was posted by the publisher. Media development like modern times is now utilized optimally by Candra Malik in preaching. Poetry as a $d a^{\prime} w a h$ media has been popular since long ago, one of the prominent figures is Hamzah Fansuri. Hamzah Fansuri in every verse contains sufismdakwah which is still widely studied. Sufi teachings delivered by Hamzah Fansuri are famous throughout the archipelago. Even the work of Hamzah Fansuri can be paralleled to sufficient poets such as Jalal al-Din Rumi[14]. Candra Malik's Sufistic ethic studies are conducted in order to be one way of addressing a problem, as a solution, as well as a guide to life for the community. In line with that, Mustafa conveys that ethics is an offer of liberation to humanity from the backward form and the development of social structures of society to build justice and virtue[15].

\section{Research Methods}

This study uses a Sufistic approach, which is an approach that emphasizes ethical teaching in tasawuf science that plays a role in everyday life. The source of the data in this study is the Anthology of \#FatwaRindu Cinta 1001 Rindu, the anthology of the Origin of Hugs, and the Love Letter from Rindu. The data of this research is the words and sentences related to ethics in the suffix fiction in the anthology. To support the deepening of the data analysis process, there is a secondary data source in the form of scientific articles published by journals and books of tasawuf. Data analysis technique in this research is through the process; Firstly, reading literary texts in the 
form of repeated Sufistic literature; second, interpreting the data already obtained from the data source; and thirdly, the conclusions taken from the analysis results are in accordance with the purpose of the study.

\section{Discussion}

Ethics in preaching have an important role in the development of an instant era. The ethics of Sufistic propaganda which are packaged in literary works by Candra Malik becomes learning for the community to know, explore, and absorb the teachings of Sufism as part of the process of understanding. This understanding process will be the stage that is passed to form wisdom in addressing every problem that exists. Widodo stated in his research that Sufistic matters were found, namely Sufism philosophy, about Sufism ethics, and the subject of the Sufism method[16]. There are three things related to ethics that will be discussed in this study, among others, ethics in attitude, ethics in conveying, ethics in inviting.

\subsection{Sufistic Ethics in Attitude}

Someone's attitude, especially from a dai is being made a role model by the community. Ethics in attitude becomes an important part of the da'wah process that is carried out. In every phenomenon that occurs in everyday life, the subject of one of the difficult attitudes is to admit mistakes and apologize. The existence of a high heart is one indication of how difficult it is to have an attitude of acknowledging mistakes and accompanied by apologies. When the existence of self gets higher, then the recognition of mistakes will increasingly not be realized, let alone being to apologize. Existence in human beings requires processing to remain at the level of balance and not carried away at the height of pride. The process of processing the existence of the self as a human being is not easy and requires a short time. In his poem Candra Malik chooses the simplest and closest attitude that could be done even though it was not easy, namely acknowledging mistakes and apologizing, as found in his work entitled Maaf, along with the lyrics; I am guilty from verbal. Until the deed. In fact, I prefer to be heard than discussed. But I prefer to talk rather than listen. Sorry, I'm sorry.

The firm attitude of acknowledging "I am guilty from verbal to acts" seems easy to do. But, in practice, not everyone can do it. Recognition of mistakes requires self-awareness to always be humble. Humility has a high and broad position so that it becomes a forum for all worldly problems. Being humble is positioning yourself physically at the lower level with the awareness that a sense of harmony from every humanitarian bond has more importance than finding the right and wrong party. The harmony in question is based on the next quotation, "In fact, I prefer to be heard than discussed. But I prefer to talk rather than listen."This quote reflects in mankind has two aspects that cannot be separated when it is contradictory. These two aspects are inherent in humans and cannot be avoided. Candra Malik in detail portrays events that occur in everyday life, one side of man likes to talk about other people and does not like to be talked about, on the other hand, humans like to be listened to rather than listening to others. This shows a natural harmony within humans.

In response to these two things, in Sufism human beings are required to always be introspective in every sense that arises. Human penchant in talking about things that are not good relates to other people, introspection becomes a principle not to do it. However, in practice it is not 
easy to apply this attitude of introspection, so humans are required to be humble to admit mistakes by being accompanied by apologies. Human life has two sides that will continue to occur and no one can stop it. It becomes an inseparable unit of the history of human creation. Humans can only try to make life-related to themselves and their surroundings run in balance with love. This can be seen from the following quote; If love, then miss. Here we are, you and me. There is never a neat love. Miss makes it mess again.

Human awareness of love is inseparable from the longing he feels every time. In every journey, humans go through a search process that is never finished. Candra Malik gives a metaphor for two aspects of human beings with love and longing. Love and longing are two things that are intertwined with each other and become a unified whole. In fact, both of them have differences that are far from each other. Love provides a sense of security and comfort while longing to destroy it with anxiety and restless. Two aspects that continue to always accompany the human journey to achieve life balance. In the process of achieving balance in life, humans are required to be able to maintain love and longing to grow together. The growth that leads to the realization that humans are made as perfect beings in terms of creating that is inserted with obstacles to be used as learning material.

\subsection{Sufistic Ethics in Delivering}

One important aspect in preaching is conveying the things contained in the Koran, hadisth, and implied messages that are spread in every aspect of life. Ethics in delivering messages to recipients of messages is not easy because the recipient of the message has different characters. In each of these differences, there is one similarity that everyone has, namely, a sense of humanity. Delivering a divine message can be done by anyone, anywhere, anytime by adjusting certain conditions and in a gentle way. The delivery of the message of divinity aims to unite every difference, but because it is delivered poorly, it is divisive. This can be seen in the work entitled The Deliberation of Heart, following the quote; Honey, do you know what can soften the tongue? Harsh words once born from houses of worship. Shouting passionately, until religion is no longer beautiful. Clenching while shouting, which besides them must be wrong. No more deliberation of heart, faith is more about winning defeat. Unfortunately, does the truth belong to the ruler of the pulpit of preaching?

Religion conveyed by violence, it does not work in accordance with the teachings of the religion itself which is the essence of uniting all differences. Therefore, ethics in delivering the message of divinity in preaching is required to be carried out with love and tenderness. The recent controversy related to religion is caused by the violence adopted by several groups. The violence that is conveyed is contained in the quote "harsh words once born from a place of worship". A place of worship known as the house of God transforms into a place that no longer gives peace to those who occupy it.

Shouts that were not pleasant to hear emerged from the mouths in the name of the religious defender group. Religion is a commodity that needs to be defended so that religion in the view of the group can be traded. Religion is no longer a teaching of the values of life that upholds humanity. Religion is a shield to do anything to gain the interests of a group. Justifying groups themselves and easily blaming other groups that are not in line. Violence for the sake of continuing violence occurs because of putting aside the conscience and the heart that should be the 
guard before and after doing a job. In the quote "No more deliberation of heart" indicates that conscience does not function as a reminder before doing something. It should be, in every work done by humans, conscience has the first and foremost role in giving a warning to the good or bad of a job. While the heart provides a second warning when the work has been completed. The deliberation of the heart which is carried out by conscience and heart should be the basis of humanity in every step taken in all aspects of life.

When the heart is not used as a sign of direction as taught by religion, then the future goal gets more obscure. As written by Candra Malik below; Who should go? Who will come back? Who will wait? It's not clear when we have no heart. The heart becomes the compass of human life heading back to the Creator. However, if the heart is no longer used, then the only thing that will be obtained is an error. With the human heart can feel between right-wrong, good-bad, and beautiful-bad. In practice, humans are not only required to hold on to the wrong right, but there is a higher value of right-wrong things, namely, good and beautiful. Something that is true is not necessarily good depending on the conditions. Therefore, in conveying the divine message, it is necessary to know the condition of the recipient of the message so that religious values are conveyed according to God's commands. However, if only holding on to the right aspects is wrong, then the opportunities for difference are as wide as the following quote; If we look for right and wrong, we cannot avoid parting.

Truth has its own version according to its division, that is, its own truth, the truth of the people, and the truth of the Righteous. Many divisions occur because the truth used is the truth in the name of a particular person or group that is not in accordance with the truth of other people or other groups that are not in line Humans are created in a sacred state that has perceptions as they are for fellow beings and in all aspects of life. Personal truths are only for personal needs that cannot be shown to others. The truth that can be conveyed to others, at least the truth of many people. So that the truth conveyed is acceptable even though this truth still has the chance of a discrepancy in a condition. The truth that should be used as the basis for preaching is the truth of the Righteous One. The truth that guarantees every creature and regardless of the tendency of certain personal and group interests.

Humans as social creatures, from birth together have feelings that are just as good as each other, there is no differentiation. Although on his journey found different things that are in accordance with their individual interests. Awareness of the situation that is experienced with good and natural as it provides an increase in understanding that it starts from fine and must end well too. That should be conveyed by every preacher to everyone that we have been fine since the beginning of creation according to the following quote; Keep in mind, we've been fine. In the quotation above it is reflected that the fellow human beings the earliest poems of creation have a fine relationship. The events that occur are initially neutral before being given meaning by each individual in accordance with the background that has been lived. 


\subsection{Sufistic Ethics in Inviting}

The next aspect that exists in da'wah activities is inviting. Invite other people to take the path determined by religious teachings. The essence of human beings in their life's journey has a great chance to fall on a misguided path, so in every prayer, it is required to always ask God to be shown a straight path. Ethics invites in Sufistic preaching demands to prioritize the presence of the heart with the aim of building understanding from the basic humanity as follows; Sheath from you. In the vastness of the universe. I found you rampant. All of your manifestations. Andenvelop me. I really asked for it. You are not your time. But the presence of the heart. Penetrate to spirituality.

The heart is the main aspect that needs to be considered in the ethics of Sufistic preaching. The presence of the heart in every human relationship provides an understanding that human values have a high value above others. The ethics of Sufistic preaching gives the opportunity that the party invited and who invites spiritual communication through the heart. Inventiveness of heart gives effect to the delivery of the message conveyed in the activity of preaching. In each of his works, Candra Malik gives a simple yet deep touch of nuance. So, when reading the work of Candra Malik who responded first, it was a heart acknowledgment of the expression of the heart through a literary work. A dai in Sufism ethics is required to link hearts with the person given the message. The connection of the heart will build spiritual relationships between human beings. The similarities raised by Candra Malik in their work often provide the basic material for unification among the many differences between individuals who have different backgrounds. Humans as living beings who have different backgrounds are actually the same, that is, they are different.

\section{Conclusion}

Candra Malik's Sufistic Da'wah contained in his works implies a message from a long journey to God based on a spiritual experience that has a long process. It can be seen from the teachings of Sufism that have an exclusive impression for many people, by Candra Malik it can be delivered in a simple and easily understood literary language. Candra Malik's works contain the concept of Sufistic charged da'wah ethics. The concept seems easy, but in practice, not everyone can do it. It takes a long process to be able to istiqamah in applying it. In the process of traveling to God, humans are required to continue to do good things even though human beings themselves tend to do things that are not good.

There are three aspects contained in Candra Malik's work related to the ethics of Sufistic preaching, among others; first, ethical behavior is reflected in self-recognition of mistakes and always apologizes with the aim of building self-awareness; second, the ethics of inviting to be found in the way taken must be smooth, gentle, and full of love; and third, the ethics of conveying in Sufism teachings must use the heart so that the message received directly enters the heart.

\section{References}

[1] S. H. Nasr, Islam dalam Cita dan Fakta (Terjemahan Abdurrahman Wahid \& Hashim Wahid). 1981.

[2] I. Ibadiyah, "Etika, Estetika, dan Religiusitas Legenda dalam Cerita Jokotole dan Dewi Ratnadi," J. Ilm. FONEMA, vol. 1, no. November, pp. 122-137, 2018. 
[3] N. Nurhayati, "Psikologi sufi," Annuha, vol. 1, no. Juli 2014, pp. 81-103, 2014.

[4] M. In'amuzzahidin, "Pemikiran Sufistik Muhammad Shalih Al-Samarani," Walisongo, vol. 20, no. November 2012, pp. 321-346, 2012.

[5] T. Tangngareng, "PUNCAK-PUNCAK CAPAIAN SUFISTIK DALAM Oleh : kehidupan rohaniyah . Dengan rohani yang suci dan bersih, sang sufi perjalanannya yakni puncak capaian sufistik . Metode perjalanan kepuncak capaian Keywords :," J. Aqidah-Ta, vol. III, no. 1, pp. 83-97, 2017.

[6] D. A. N. F. Rahman, "Perjalanan Mistik Tokoh Wallaili Wannahar dalam Novel Layla Karya Candra Malik ( Kajian Sufistik Fariduddin Attar )," vol. 1, no. 2018, pp. 0-19.

[7] N. M. Ulfah, "Etika Dalam Kehidupan Modern : Studi Pemikiran Sufistik Hamka," Esoter. J. Akhlak dan Tasawuf, vol. 2, no. 1, pp. 95-105, 2016.

[8] S. Huda, "TASAWUF SEBAGAI AKHLAK: Kajian Tekstual atas Kata-Kata Emas Shaykh Muhammad Raheem Bawa Muhaiyaddeen," Menara Tebuireng, vol. 9, no. Maret 2014, pp. 127-151, 2014.

[9] Asep Supriadi, "Dimensi Sufistik dalam Puisi “Cermin' Karya Sutardji Calzoum Bachri," Metasastra, vol. 3, no. 1, pp. 1-8, 2010.

[10] Sugeng Riadi, "NILAI-NILAI SUFISTIK DAN NILAI-NILAI PEDAGOGIK TRANSFORMATIF DALAM NOVEL SYAIKH SITI JENAR KARYA AGUS SUNYOTO: STUDI STRUKTURALISME GENETIK," in Prosiding Kolokium Doktor dan Seminar Hasil Penelitian Hibah Tahun 2016, 2016, pp. 233-247.

[11] Afrizal Nur, "Menguak Dimensi Sufistik dalam Interpretasi Alquran," J. ushuluddin, vol. XX, no. 2, pp. 185-198, 2013.

[12] L. Andarwati, "Sufisme Perkotaan dan Pedesaan di Era Modernisasi dan Sekularisasi," Universum, vol. 10, no. Januari 2016, pp. 41-48, 2016.

[13] S. Futaqi, "NALAR SUFISTIK ISLAM NUSANTARA DALAM MEMBANGUN PERDAMAIAN.".

[14] Zakaria, "Dakwah Sufistik Hamzah Fansuri (Kajian Substantif Terhadap Syair Perahu," Islam Futur., vol. 13, no. 1, pp. 105-126, 2013.

[15] M. Mustafa, Agama dan Bayang-bayang Etis Syekh Yusuf Al-Makassari. Yogyakarta: LKiS Yogyakarta., 2011.

[16] Widodo dan Rusdian Noor Dermawan, "PERIHAL SUFISTIK DALAM NOVEL BEKISAR MERAH KARYA AHMAD TOHARI: SEBUAH PENDEKATAN SEMIOTIKA,” Caraka, vol. 4, no. Juni 2018, 2018. 